2013s-33

\title{
Educational Attainment, Wages and Employment of Second-Generation Immigrants in France
}

Gabin Langevin, David Masclet, Fabien Moizeau, Emmanuel Peterle

\section{Série Scientifique \\ Scientific Series}

\section{Montréal}

Septembre 2013

(C) 2013 Gabin Langevin, David Masclet, Fabien Moizeau, Emmanuel Peterle. Tous droits réservés. All rights reserved. Reproduction partielle permise avec citation du document source, incluant la notice $\subset$.

Short sections may be quoted without explicit permission, if full credit, including (C) notice, is given to the source.
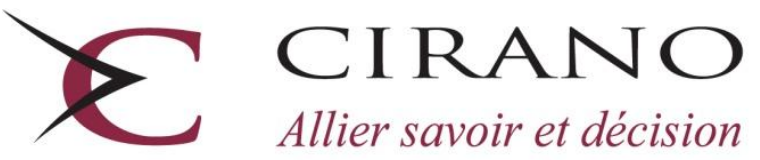

Allier savoir et décision

Centre interuniversitaire de recherche en analyse des organisations 


\section{CIRANO}

Le CIRANO est un organisme sans but lucratif constitué en vertu de la Loi des compagnies du Québec. Le financement de son infrastructure et de ses activités de recherche provient des cotisations de ses organisations-membres, d'une subvention d'infrastructure du Ministère du Développement économique et régional et de la Recherche, de même que des subventions et mandats obtenus par ses équipes de recherche.

CIRANO is a private non-profit organization incorporated under the Québec Companies Act. Its infrastructure and research activities are funded through fees paid by member organizations, an infrastructure grant from the Ministère du Développement économique et régional et de la Recherche, and grants and research mandates obtained by its research teams.

\section{Les partenaires du CIRANO}

\section{Partenaire majeur}

Ministère de l'Enseignement supérieur, de la Recherche, de la Science et de la Technologie

Partenaires corporatifs

Autorité des marchés financiers

Banque de développement du Canada

Banque du Canada

Banque Laurentienne du Canada

Banque Nationale du Canada

Banque Scotia

Bell Canada

BMO Groupe financier

Caisse de dépôt et placement du Québec

Fédération des caisses Desjardins du Québec

Financière Sun Life, Québec

Gaz Métro

Hydro-Québec

Industrie Canada

Investissements PSP

Ministère des Finances et de l'Économie

Power Corporation du Canada

Rio Tinto Alcan

State Street Global Advisors

Transat A.T.

Ville de Montréal

\section{Partenaires universitaires}

École Polytechnique de Montréal

École de technologie supérieure (ÉTS)

HEC Montréal

Institut national de la recherche scientifique (INRS)

McGill University

Université Concordia

Université de Montréal

Université de Sherbrooke

Université du Québec

Université du Québec à Montréal

Université Laval

Le CIRANO collabore avec de nombreux centres et chaires de recherche universitaires dont on peut consulter la liste sur son site web.

Les cahiers de la série scientifique (CS) visent à rendre accessibles des résultats de recherche effectuée au CIRANO afin de susciter échanges et commentaires. Ces cahiers sont écrits dans le style des publications scientifiques. Les idées et les opinions émises sont sous l'unique responsabilité des auteurs et ne représentent pas nécessairement les positions du CIRANO ou de ses partenaires.

This paper presents research carried out at CIRANO and aims at encouraging discussion and comment. The observations and viewpoints expressed are the sole responsibility of the authors. They do not necessarily represent positions of CIRANO or its partners. 


\title{
Educational Attainment, Wages and Employment of Second-Generation Immigrants in France*
}

\author{
Gabin Langevin ${ }^{\dagger}$, David Masclet $t^{\dagger}$, Fabien Moizeau ${ }^{\S}$ Emmanuel Peterle E** $^{* *}$
}

\begin{abstract}
Résumé/abstract
We use data from the Trajectoires et Origines survey to analyze the labor-market outcomes of both second-generation immigrants and their French native counterparts. Second-generation immigrants have on average a lower probability of employment and lower wages than French natives. We find however considerable differences between second-generation immigrants depending on their origin: while those originating from Northern Africa, Sub-Saharan Africa and Turkey are less likely to be employed and receive lower wages than French natives, secondgeneration immigrants with Asian or Southern- and Eastern-European origins do not differ significantly from their French native counterparts. The employment gap between French natives and second generation immigrants is mainly explained by differences in their education; education is also an important determinant of the ethnic wage gap. Finally we show that these differences in educational attainment are mainly explained by family background. Although the role of discrimination cannot be denied, our findings do point out the importance of family background in explaining lifelong ethnic inequalities.
\end{abstract}

Mots clés/keywords : labor-market discrimination, second-generation immigrants, educational attainment, family background, decomposition methods.

Codes JEL : I2, J15, J24, J41

\footnotetext{
* The authors are very grateful to Caroline Berchet for her comments on an earlier version of this paper. The authors also thank participants at the 2013 Journées de Microéconomie Appliquée (Nice) and the 2013 CREMINRA Workshop (Rennes). Financial support from the Agence Nationale de la Recherche (ANR-12-INEG-0002) is gratefully acknowledged.

† CREM (CNRS - Université de Rennes 1), 7, place Hoche, 35065 Rennes, France.

Tel.: +33223233558 E-mail: gabin.langevin@univ-rennes1.fr.

* CREM (CNRS - Université de Rennes 1) and CIRANO, 7, place Hoche, 35065 Rennes, France.

Tel.: +33223 2333 18. E-mail: david.masclet@univ-rennes1.fr.

${ }^{\S}$ CREM (CNRS - Université de Rennes 1) and Institut Universitaire de France, 7, place Hoche, 35065 Rennes, France. Tel.: +33223 2335 87. E-mail: fabien.moizeau@univ-rennes1.fr.

** CREM (CNRS - Université de Rennes 1), 7, place Hoche, 35065 Rennes, France.

Tel.: +33223 2335 58. E-mail: emmanuel.peterle@univ-rennes1.fr.
} 


\section{Introduction}

In November 2005, a wave of violence swept through the suburbs of a number of French cities. Faced with this sudden rise in tension, some commentators underlined long-standing integration problems, including discrimination against minorities and the lack of job opportunities in the suburbs which are mainly populated by immigrants. The living standards of individuals with immigrant parents in France are on average 14\% lower than those of natives with French parents (Lombardo and Pujol, 2011). However, despite the acknowledgment of such tensions linked to immigration, the empirical analysis of ethnic employment and wage gaps in France is surprisingly sparse. A few notable exceptions are the recent contributions of Aeberhardt and Pouget (2010), Aeberhardt et al. (2010a,b) and Belzil and Poinas (2010). The French situation is in sharp contrast to the vast literature on racial discrimination and the social integration of immigrants in a number of other countries (see Altonji and Blank, 1999 and Borjas, 1999 for surveys). One likely explanation is that, until recently, information regarding ethnicity was not collected in French survey data. ${ }^{1}$

We here aim to contribute to the existing literature by investigating lifelong ethnic inequalities in France and their determinants. Precisely our aim is threefold. We first consider the extent to which employment and wages are affected by ethnic origin. We separate the latter into eight groups: North African, Sub-Saharan African, Turkish, Asian, Southern European, Northern European, Eastern European and French origin. We then test whether the gaps between French natives ${ }^{2}$ and second-generation immigrants reflect discrimination or rather differences in education and occupational positions. Discrimination is often invoked as a possible cause of the racial employment and wage gaps. However it can also be reasonably conjectured that these gaps reflect differences in characteristics such as education. After underlining the central role of education in both the ethnic employment and wage gaps, we focus on the determinants of education. This constitutes the third aim of this paper.

Our analysis is based on data from the Trajectoires et Origines $(\mathrm{TeO})$ survey, which was carried out jointly by the INED and INSEE in 2008 and 2009 in metropolitan France. While other surveys have considered integration and discrimination in France, to our knowledge this is the only French survey to investigate in detail the situation of both first- and second-

\footnotetext{
${ }^{1}$ The French egalitarian ideal, which rejects any form of categorization into ethnic groups, is often evoked to explain that lack of ethnic information in French survey data.

${ }^{2}$ Note that, for convenience, we consider as French natives only those respondents whose parents were both born with French nationality, although from a legal point of view, immigrants' descendants born in France are also French natives as a result of the French jus solis.
} 
generation immigrants on the labor market. The survey contains a large number of sociodemographic and economic variables, such as socio-economic outcomes (education, employment and housing) at the time of the interview (2008), migratory history, ethnic belonging (ties with the home country, religion, languages and ethnic identity) but also previous education - both at school and in the family. These data allow us to disentangle the roles played by ethnic belonging and other variables such as education in explaining the employment and wage gaps between French natives and second-generation immigrants.

Our paper is related to existing work on the labor-market outcomes of immigrants (see for instance Dustmann et al., 2008, and Algan et al., 2010). In particular, our analysis is closely related to the seminal papers of Aeberhardt and Pouget (2010) and Aeberhardt et al. (2010a) which also consider the wage gap between second-generation immigrants and French natives. Aeberhardt and Pouget (2010) analyze national-origin wage differentials in France. They find that these wage gaps mostly reflect differences in the type of jobs individuals take up, according to their experience, background and education. Using data from the "Formation Qualification Professionnelle" survey, Aeberhardt et al. (2010a) investigate the wage and employment gaps between French natives and French workers with at least one African parent. They conclude that the unexplained portion of the employment decomposition is much larger than that of the wage decomposition. Labor market discrimination in France is found to be more frequent at the hiring stage than in earnings. A similar empirical analysis of "Emploi en Continu" data confirms these findings (see Aeberhardt et al., 2010b).

The work we present here differs from this literature in a number of ways. First, we emphasize the role of education in explaining ethnic labor-market differences. In this respect, our work belongs to the strand of literature on the educational gaps between natives and immigrants (see for instance Gang and Zimmerman, 2000; Van Ours and Veenman, 2001; Domingues Dos Santos and Wolff, 2011, and Brinbaum et al., 2012). In particular, Brinbaum et al. (2012) also use TeO data to examine differences in education between natives, secondgeneration immigrants, and immigrants whose education in France began at the primary school level. Our approach differs from theirs as we focus on lifelong ethnic inequalities. Our paper is more closely related to that of Belzil and Poinas (2010), who estimate a dynamic model of schooling choices and early access to permanent employment contracts in France. Using data from the "Generation 98" survey, Belzil and Poinas (2010) investigate the differences between second-generation immigrants and their French-native counterparts in terms of access to permanent employment contracts. Education is found to be the main 
determinant of permanent-employment differentials. After controlling for education and other observed characteristics, ethnic origin explains less than $6 \%$ of this employment gap. However, in contrast to Belzil and Poinas (2010) who only consider permanent employment contracts in the early career, we here also focus on the determinants of wages. Our data enable us to conduct a deeper analysis of the determinants of education gaps between ethnic groups, as they contain a large number of variables with respect to parental background as well as the social and housing environment. The work here is also original in that it extends the analysis to a number of different sub-populations of second-generation immigrants (North African, Sub-Saharan African, Turkish, Asian, Eastern European, Northern European and Southern European) instead of only focusing on the comparison between French and African natives. This allows us to see whether and why some second-generation immigrants are more likely than others to suffer from earnings and employment gaps.

To preview our findings, we show that: $i$ ) second-generation immigrants are on average less likely to be employed and receive lower wages than French natives; ii) there is considerable heterogeneity among immigrants - those from North Africa, Sub-Saharan Africa and Turkey are less likely to be employed and receive lower wages than French natives, while those with Asian or European origins are statistically the same as French natives regarding wages and employment; iii) a large part of the labor-market differences between French natives and second-generation immigrants can be attributed to differences in education; and $i v)$ this education gap seems to be rooted in ethnic differences in family backgrounds.

The remainder of the paper is organized as follows. Section 2 presents the $T e O$ survey and our analysis sub-sample. Section 3 then presents our main findings, and Section 4 discusses them. Last, Section 5 concludes.

\section{Data}

\subsection{The $\mathrm{TeO}$ survey}

Our work is based on data from the cross-section Trajectoires et Origines survey. This survey was jointly carried out by INED and INSEE in 2008 and 2009 in metropolitan France, and covered 21,000 individuals aged from 18 to 60 years via face-to-face interviews. The TeO data include a wide range of variables regarding immigrants' living conditions and social mobility. Both education and labor-market profiles are recorded, allowing the lifecourse to be investigated. The survey also contains additional information about the migratory history, and 
the family and social context during both childhood and adulthood. The variables can be broadly organized into three main groups: family and social background (parents' statuses, siblings, and marital life); socio-economic outcomes (education, employment, and housing); and migratory history and ethnic belonging (ties to the home country, religion, languages, and ethnic identity).

Following the French Republican egalitarian principle, migrants' offspring are not usually visible in national statistics. This was dealt with in the $T e O$ survey by cross-checking with the 2007 French census and local registers to identify first-generation immigrants' children (in particular from birth certificates). The $\mathrm{TeO}$ data thus allows the socio-economic integration of both first- and second-generation migrants to be analyzed, both of which were on purpose oversampled. Weights are provided to render the sample nationally representative. The dataset is composed of 3781 individuals from the reference population ("natives", hereafter), 8456 immigrants, and 8161 descendants of immigrants.

\subsection{Scope of the analysis}

We here consider labor-market outcomes, and in particular the impact of education on employment and wages. This aim implies a restrictive - but consistent - choice of sample. Specifically, we do not include first-generation immigrants given that they in general did not go through the French education system. Our final sample thus consists of employees and the unemployed among French natives and second-generation immigrants. We consider neither students nor the retired, and drop individuals with missing values for wages or labor-force status. ${ }^{3}$ Our final analysis sample consists of 8325 respondents.

We have two main types of variables of interest. First, we consider labor-market outcomes, as given by hourly wages and employment in 2008. Second, as we are interested in the potential life-course effects of early differences (in terms of the family context during childhood, notably), we focus on the determinants of educational success.

\footnotetext{
${ }^{3}$ We also deliberately exclude self-employed workers from our data analysis. The reason is that self-employed who are their "own boss" have no reason to discriminate against themselves neither at the employment level nor at the wage level. Note however that self-employed may suffer from another form of discrimination, namely "consumer discrimination". Consumer discrimination may induce significant ethnic differences in both selfemployment rates and incomes. The reason of consumer discrimination is that, for instance white consumers may dislike purchasing goods from services from blacks and other minorities (see Becker, 1971; Borjas, and Bronars, 1989).
} 


\subsection{Sub-populations of interest}

As noted above, we contrast different subsamples of second-generation immigrants (5691 respondents) and natives (2634 respondents). In the second-generation subsample individuals have at least one parent originating from North Africa (1492 respondents), Sub-Saharan Africa (478), Turkey (326), Southern Europe (2254), Northern Europe (435), Eastern Europe (346) or Asia (360). ${ }^{4}$ When both parents are immigrants, but from two different areas, we retain the father's origin. ${ }^{5}$

\section{Methodology and results}

After presenting some summary statistics, we investigate the determinants of both employment and wages. We first estimate employment regressions, and then appeal to the methods popularized by Oaxaca (1973) and Blinder (1973) to decompose the employment gap into a structural part resulting from differences in observable characteristics and a residual part resulting from differences in the return to these same characteristics. In a second step, we consider the differences in wages across ethnic groups. Following Aeberhardt et al. (2010a), we correct for the potential selection bias due to wages only being observed for the employed. This correction is effected via a two-step Heckman procedure. Last, we evaluate the determinants of differences in education between ethnic groups.

\subsection{Summary statistics}

Table 1 presents the descriptive statistics regarding employment status and hourly wages among ethnic groups in our sample.

\footnotetext{
${ }^{4}$ We define the European sub-groups as follows. Southern Europe comprises Italy (36.46\% of this sub-group), Portugal (32.67\%), Spain (30.19\%) and Greece (0.68\%). Northern Europe contains Germany (43.02\% of this sub-group), Belgium (32.48\%), United Kingdom (9.40\%); Netherlands (3.42\%), Ireland (3.42\%), Austria $(3.13 \%)$, Luxembourg $(2.28 \%)$, Denmark $(1.71 \%)$, Sweden $(1.14 \%)$. Eastern Europe contains all of the remainder of the European continent. Second-generation immigrants from America, Oceania and Middle East countries are dropped due to small cell sizes.

${ }^{5}$ Individuals with parents from two different immigrant groups represent only $0.98 \%$ of our second-generation immigrant sample (82 observations).
} 
Table 1 - Summary statistics on labor-market outcomes by ethnic group

\begin{tabular}{|c|c|c|c|c|}
\hline Origin of parents & $\begin{array}{l}\text { Employment } \\
\text { share }\end{array}$ & $\begin{array}{c}\text { Significantly } \\
\text { different from } \\
\text { France? } \\
\end{array}$ & Hourly wage & $\begin{array}{l}\text { Significantly different } \\
\text { from France? }\end{array}$ \\
\hline France & $\begin{array}{l}90.3 \% \\
(0,007)\end{array}$ & - & $\begin{array}{l}10.920 \\
(0.230)\end{array}$ & - \\
\hline North Africa & $\begin{array}{l}77.1 \% \\
(0.014)\end{array}$ & $\begin{array}{c}\text { Yes } \\
(\mathrm{F}=69.07 \\
\mathrm{p}=0.000)\end{array}$ & $\begin{array}{c}9.054 \\
(0.120)\end{array}$ & $\begin{array}{c}\text { Yes } \\
(\mathrm{t}=-7.18 ; \mathrm{p}=0.000)\end{array}$ \\
\hline Sub-Saharan Africa & $\begin{array}{l}77.9 \% \\
(0.026)\end{array}$ & $\begin{array}{c}\text { Yes } \\
(\mathrm{F}=20.35 \\
\mathrm{p}=0.000)\end{array}$ & $\begin{array}{c}9.372 \\
(0.420)\end{array}$ & $\begin{array}{c}\text { Yes } \\
(\mathrm{t}=-3.23 ; \mathrm{p}=0.001)\end{array}$ \\
\hline Turkey & $\begin{array}{l}69.2 \% \\
(0.052)\end{array}$ & $\begin{array}{c}\text { Yes } \\
(\mathrm{F}=16,35 ; \\
\mathrm{p}=0.000)\end{array}$ & $\begin{array}{c}9.249 \\
(0.479)\end{array}$ & $\begin{array}{c}\text { Yes } \\
(\mathrm{t}=-3.14 ; \mathrm{p}=0.002)\end{array}$ \\
\hline Asia & $\begin{array}{l}85.1 \% \\
(0.027)\end{array}$ & $\begin{array}{c}\text { Yes } \\
(F=3.32 \\
p=0.065)\end{array}$ & $\begin{array}{l}10.448 \\
(0.346)\end{array}$ & $\begin{array}{c}\text { No } \\
(\mathrm{t}=-1.13 ; \mathrm{p}=0.257)\end{array}$ \\
\hline Southern Europe & $\begin{array}{l}90.4 \% \\
(0.018)\end{array}$ & $\begin{array}{c}\text { No } \\
(\mathrm{F}=0.00 ; \\
\mathrm{p}=0.9488)\end{array}$ & $\begin{array}{l}10.213 \\
(0.231)\end{array}$ & $\begin{array}{c}\text { Yes } \\
(\mathrm{t}=-2.17 ; \mathrm{p}=0.030)\end{array}$ \\
\hline Northern Europe & $\begin{array}{l}95.7 \% \\
(0.011)\end{array}$ & $\begin{array}{c}\text { Yes } \\
(\mathrm{F}=15.77 \\
\mathrm{p}=0.000)\end{array}$ & $\begin{array}{l}12.150 \\
(0.515)\end{array}$ & $\begin{array}{c}\text { Yes } \\
(\mathrm{t}=2.18 ; \mathrm{p}=0.030)\end{array}$ \\
\hline Eastern Europe & $\begin{array}{l}77.9 \% \\
(0.100)\end{array}$ & $\begin{array}{c}\text { No } \\
(F=1.52 ; \\
p=0.218)\end{array}$ & $\begin{array}{l}10.901 \\
(0.417)\end{array}$ & $\begin{array}{c}\text { No } \\
(t=-0.04 ; p=0.967)\end{array}$ \\
\hline
\end{tabular}

Note: The table shows the weighted means, with weighted standard deviations in parentheses.

In Table 1 there are considerable employment and wage differences between secondgeneration immigrants and French natives, and also between immigrant groups. Secondgeneration immigrants with North-African, Sub-Saharan African and Turkish parents are less likely to be in employment than are natives with French parents and receive lower wages on average. Southern-European immigrant descendants have a lower (but not significantly so) employment probability but earn on average higher wages. Remarkably, Northern-European immigrant descendants perform better than do the French regarding both employment and wages. Last, Table 1 reveals that the children of Asian parents suffer less from lower employment than do some other immigrant-origin groups. ${ }^{6}$

\footnotetext{
${ }^{6}$ Weighted hourly wage means are compared via a t-test. We use the Rao and Scott (1984) second-order correction of the Pearson $x^{2}$-test to analyze employment differences. We here consider the $10 \%$ significance threshold.
} 


\subsection{The determinants of the ethnic employment gap}

To provide more formal evidence of an ethnic employment gap, we run employment regressions. Let the employment function for individual $i$ in ethnic group $j$ be given by

$$
\begin{aligned}
& L_{i j}=1_{L_{i j}^{*}>0} \\
& L_{i j}^{*}=H_{i j} \cdot \alpha+\omega_{j}+\varepsilon_{i j}
\end{aligned}
$$

where $L_{i j}$ is a dummy variable corresponding to employment, $L_{i j}^{*}$ is the associated latent variable, $H_{i j}$ is a vector of the determinants of employment, and $\omega_{j}$ is a group $j$ fixed effect. Setting $\omega_{\text {France }}$ equal to 0 fixes natives born to French parents as the reference group. The error term $\varepsilon_{i j}$ is assumed to follow a normal distribution with parameters $(0,1)$. The probability of employment is expressed as

$$
\operatorname{Prob}\left(L_{i j}=1\right)=\operatorname{Prob}\left(L_{i j}^{*}>0\right)=\operatorname{Prob}\left(\varepsilon_{i j}>-\left(H_{i j} \cdot \alpha+\omega_{j}\right)\right)=\Phi\left(H_{i j} \cdot \alpha+\omega_{j}\right)
$$

where $\Phi($.$) is the standard normal cumulative distribution function.$

Table 2 shows the results from weighted ${ }^{7}$ probit estimation of employment. To emphasize the role of education in ethnic employment gaps, we run estimates with and without the education variables.

\footnotetext{
${ }^{7}$ We use the pweight command in Stata10 to include weights in our models.
} 
Table 2 - Employment estimates

\begin{tabular}{|c|c|c|}
\hline & \multicolumn{2}{|c|}{ Marginal effects from weighted probit estimation } \\
\hline & $(1)$ & $(2)$ \\
\hline Age & $\begin{array}{c}-0.005 * * \\
(0.002)\end{array}$ & $\begin{array}{c}-0.020 * * * \\
(0.003)\end{array}$ \\
\hline Experience & $\begin{array}{c}0.012 * * * \\
(0.003)\end{array}$ & $\begin{array}{c}0.027 * * * \\
(0.004)\end{array}$ \\
\hline Experience $2 / 100$ & $\begin{array}{c}-0.012 * * \\
(0.005)\end{array}$ & $\begin{array}{c}-0.010 * * \\
(0.005)\end{array}$ \\
\hline Education & & \\
\hline No qualifications & & Ref. \\
\hline Junior high school degree & & $\begin{array}{c}0.066^{* * * *} \\
(0.10)\end{array}$ \\
\hline Vocational high school degree & & $\begin{array}{c}0.103 * * * \\
(0.015)\end{array}$ \\
\hline High school degree & & $\begin{array}{c}0.085 * * * \\
(0.007)\end{array}$ \\
\hline College degree & & $\begin{array}{c}0.107 * * * \\
(0.009)\end{array}$ \\
\hline University degree & & $\begin{array}{c}0.143 * * * \\
(0.011)\end{array}$ \\
\hline Origin & & \\
\hline French native & Ref. & Ref. \\
\hline North African & $\begin{array}{c}-0.094 * * * \\
(0.019)\end{array}$ & $\begin{array}{c}-0.039 * * * \\
(0.015)\end{array}$ \\
\hline Sub-Saharan African & $\begin{array}{c}-0.060 * * \\
(0.031)\end{array}$ & $\begin{array}{l}-0.019 \\
(0.024)\end{array}$ \\
\hline Turkish & $\begin{array}{c}-0.101 * * * \\
(0.044)\end{array}$ & $\begin{array}{c}-0.042 \\
(0.034)\end{array}$ \\
\hline Asian & $\begin{array}{l}-0.010 \\
(0.023)\end{array}$ & $\begin{array}{c}0.000 \\
(0.021)\end{array}$ \\
\hline Southern European & $\begin{array}{c}0.008 \\
(0.014)\end{array}$ & $\begin{array}{c}0.029 * * \\
(0.011)\end{array}$ \\
\hline Northern European & $\begin{array}{c}0.058 * * * \\
(0.014)\end{array}$ & $\begin{array}{c}0.050 * * * \\
(0.012)\end{array}$ \\
\hline Eastern European & $\begin{array}{l}-0.115 \\
(0.094)\end{array}$ & $\begin{array}{l}-0.100 \\
(0.094)\end{array}$ \\
\hline Mixed origin (French+other) & $\begin{array}{c}-0.017 \\
(0.018)\end{array}$ & $\begin{array}{c}-0.018 \\
(0.016)\end{array}$ \\
\hline Family & & \\
\hline At least one child & $\begin{array}{l}-0.030 * \\
(0.017)\end{array}$ & $\begin{array}{c}-0.023 \\
(0.016)\end{array}$ \\
\hline Single man & Ref. & Ref. \\
\hline Single woman & $\begin{array}{c}0.001 \\
(0.018)\end{array}$ & $\begin{array}{l}-0.009 \\
(0.018)\end{array}$ \\
\hline Man, working spouse & $\begin{array}{c}0.112 * * * \\
(0.013)\end{array}$ & $\begin{array}{c}0.093 * * * \\
(0.011)\end{array}$ \\
\hline Woman, working spouse & $\begin{array}{c}0.073 * * * \\
(0.015)\end{array}$ & $\begin{array}{c}0.055^{* * * *} \\
(0.014)\end{array}$ \\
\hline Man, non-working spouse & $\begin{array}{c}0.065 * * * \\
(0.014)\end{array}$ & $\begin{array}{c}0.057 * * * \\
(0.012)\end{array}$ \\
\hline Woman, non-working spouse & $\begin{array}{c}0.015 \\
(0.034)\end{array}$ & $\begin{array}{c}0.019 \\
(0.028)\end{array}$ \\
\hline Controls for city size & Yes & Yes \\
\hline Pseudo $\mathrm{R}^{2}$ & 0.089 & 0.173 \\
\hline Observations & 8154 & 8154 \\
\hline
\end{tabular}

Notes: *** Significant at the 0.01 level, ** at the 0.05 level, * at the 0.10 level. Standard errors are in parentheses. 
Columns (1) and (2) show the estimated coefficients without and with controls for education respectively. We include a number of individual characteristics such as age, experience, gender and marital status. In column (1), individuals of North African, SubSaharan African and Turkish origin have a significantly lower probability of employment than do natives. By way of contrast, Northern-European descendants perform significantly better than do French natives, with an employment probability which is 5.8 percentage points higher. The insignificant coefficients on the Asian and Southern or Eastern European variables show that there is no employment difference between these groups and French natives. Controlling for education in column (2) renders the coefficients on the Sub-Saharan African and Turkish variables insignificant. The employment probability gap for individuals of North-African origin rather than French origin drops from 9. to 3.9 percentage points in column (2), and the Southern European coefficient is now positive and significant. The results in Table 2 thus show that the ethnic employment gap is significantly reduced by controlling for education.

To provide further evidence of the extent of the ethnic employment gap, we use the decomposition method introduced by Aeberhardt et al. (2010a). This provides estimates for non-linear regressions analogous to those from standard linear decomposition techniques (Oaxaca, 1973; Blinder, 1973; Neuman and Oaxaca, 2004; Bauer and Sinning, 2008). This allows us to decompose the employment gap between two groups into a part resulting from differences in observable characteristics such as education and a residual part. The main attraction of the Aeberhardt et al. (2010a) method is that it does not involve the calculation of coefficients for the minority groups. Due to the small cell sizes of immigrant-origin groups, separate regressions may yield inaccurate coefficient estimates. The decomposition of the employment gap between natives and second-generation immigrants from group $j$ is given by:

$$
\begin{aligned}
E\left[L_{i f}\right]-E\left[L_{i j}\right] & =\underbrace{E_{H f}\left[\mathrm{E}\left(L_{i f} \mid H i\right)\right]-E_{H j}\left[\mathrm{E}\left(L_{i f} \mid H i\right)\right]}_{\text {Explained part }} \\
& +\underbrace{E_{H j}\left[\mathrm{E}\left(L_{i f} \mid H i\right)\right]-E_{H j}\left[\mathrm{E}\left(L_{i j} \mid H i\right)\right]}_{\text {Residual gap }}
\end{aligned}
$$

The explained part consists of the difference between French natives' employment and the estimated employment of second-generation immigrants from group $j$, when both groups have similar returns to characteristics. This part of the employment gap results from differences in characteristics only. On the other hand, the residual gap consists of the part of employment gap attributed to differences in the return to characteristics. 
Following Aeberhardt et al. (2010a,b), we use simple empirical counterparts to carry out this decomposition.

$$
\begin{aligned}
& \frac{1}{N_{f}} \sum_{i \epsilon f} L_{i} \stackrel{a . s}{\rightarrow} E_{H f}\left[\mathrm{E}\left(L_{i f} \mid H i\right)\right] \\
& \frac{1}{N_{j}} \sum_{i \epsilon j} L_{i} \stackrel{a . s}{\rightarrow} E_{H j}\left[\mathrm{E}\left(L_{i j} \mid H i\right)\right] \\
& \frac{1}{N_{j}} \sum_{i \epsilon j} \Phi\left(H_{i} . \alpha_{f}\right) \stackrel{a . s}{\rightarrow} E_{H j}\left[\mathrm{E}\left(L_{i f} \mid H i\right)\right]
\end{aligned}
$$

Equations (5) and (6) are the simple arithmetical means of employment levels in groups $f$ and $j$. Equation (7) implies calculating the coefficients $\alpha_{f}$ in a previous regression on the French native population only, and applying them to second-generation immigrants from group $j$. Although this method does not lead to an exact decomposition, it has been shown to yield more precise estimates than the usual approach (Aeberhardt et al., 2010a,b).

Table 3 shows the results of the employment-gap decompositions between French natives and second-generation immigrants. The procedure is applied with and without control for education in order to assess its impact on employment access. In the left panel, there are no education controls. We use the same covariates as in the regressions in Table 2, apart for the ethnic group dummies of course.

With no education controls, second-generation immigrants from North Africa, SubSaharan Africa, Eastern Europe or Turkey face a considerable residual employment gap. However, controlling for education sharply reduces this gap. Again, education is a major determinant of ethnic differences in employment. There remains nonetheless a substantial residual gap which may reflect, amongst many other phenomena, discrimination (Section 4 further discusses that the residual gap may not only reflect discrimination). 
Table 3 - The decomposition of the employment gap between French natives and secondgeneration immigrants

\begin{tabular}{|c|c|c|c|c|c|c|}
\hline & \multicolumn{3}{|c|}{ No control for education } & \multicolumn{3}{|c|}{ Controlling for education } \\
\hline \multirow[b]{2}{*}{ North African } & Raw & Explained & Residual & Raw & Explained & Residual \\
\hline & 0.141 & $\begin{array}{c}0.032 \\
23.04 \%\end{array}$ & $\begin{array}{c}0.108 \\
76.96 \%\end{array}$ & 0.141 & $\begin{array}{c}0.087 \\
61.66 \%\end{array}$ & $\begin{array}{c}0.054 \\
38.34 \%\end{array}$ \\
\hline $\begin{array}{l}\text { Sub-Saharan } \\
\text { African }\end{array}$ & 0.134 & $\begin{array}{c}0.048 \\
35.96 \%\end{array}$ & $\begin{array}{c}0.085 \\
64.04 \%\end{array}$ & 0.134 & $\begin{array}{c}0.094 \\
70.11 \%\end{array}$ & $\begin{array}{c}0.040 \\
29.89 \%\end{array}$ \\
\hline Turkish & 0.195 & $\begin{array}{c}0.077 \\
39.34 \%\end{array}$ & $\begin{array}{c}0.118 \\
60.66 \%\end{array}$ & 0.195 & $\begin{array}{c}0.144 \\
73.86 \%\end{array}$ & $\begin{array}{c}0.051 \\
26.14 \%\end{array}$ \\
\hline Asian & 0.055 & $\begin{array}{c}0.035 \\
63.54 \%\end{array}$ & $\begin{array}{c}0.020 \\
36.46 \%\end{array}$ & 0.055 & $\begin{array}{c}0.056 \\
101.81 \%\end{array}$ & $\begin{array}{l}-0.001 \\
-1.81 \%\end{array}$ \\
\hline $\begin{array}{l}\text { Southern } \\
\text { European }\end{array}$ & Not signif. & & & Not signif. & & \\
\hline $\begin{array}{l}\text { Northern } \\
\text { European }\end{array}$ & -0.055 & $\begin{array}{l}-0.008 \\
14.55 \%\end{array}$ & $\begin{array}{l}-0.047 \\
85.66 \%\end{array}$ & -0.055 & $\begin{array}{l}-0.017 \\
30.91 \%\end{array}$ & $\begin{array}{l}-0.038 \\
69.09 \%\end{array}$ \\
\hline $\begin{array}{l}\text { Eastern } \\
\text { European }\end{array}$ & 0.114 & $\begin{array}{c}-0.014 \\
-12.51 \%\end{array}$ & $\begin{array}{c}0.128 \\
112.51 \%\end{array}$ & 0.114 & $\begin{array}{l}-0.002 \\
-1.85 \%\end{array}$ & $\begin{array}{c}0.116 \\
101.85 \%\end{array}$ \\
\hline
\end{tabular}

\subsection{Wage differentials between ethnic groups.}

After having investigated the employment ethnic gap, we now turn to the ethnic wage gap. Following Aeberhardt et al. (2010a,b), we control for selection using the Heckman two-step procedure. ${ }^{8}$ We assume that the wage function is given by

$$
w_{i j}=X_{i j} \cdot \beta+\delta_{j}+u_{i j}
$$

where $w_{i j}$ is the log hourly wage of individual $i$ belonging to ethnic group $j, X_{i j}$ is a vector of the determinants of market wages (this latter has a coefficient vector $\beta$ which applies to the whole population) and $\delta_{j}$ is a parameter specific to ethnic group $j$. Considering French natives as the omitted category, we set $\delta_{\text {France }}=0$. As such, $\delta_{j}$ measures the wage gap between group $j$ and France, conditional on the other covariates. Last, $u_{i j}$ is an error term which is assumed to follow a normal distribution with parameters $\left(0, \sigma_{u}\right)$. We also assume that $\operatorname{cov}\left(\varepsilon_{\mathrm{ij}}, \mathrm{u}_{\mathrm{ij}}\right)=\rho$, for any $i, j$.

\footnotetext{
${ }^{8}$ We appeal to maximum-likelihood estimators, which are known to be more efficient than the original two-step procedure (Puhani, 2000).
} 
The wage is however only observed for individuals in employment. Let the employment function for individual $i$ in ethnic group $j$ be

$$
L_{i j}^{*}=H_{i j} \cdot \alpha+\omega_{j}+\varepsilon_{i j}
$$

The presence of possible correlation $\rho$ between the error terms of our two equations implies potential bias. We estimate the wage equation for the employed, which is expressed as

$$
\begin{aligned}
& w_{i j} \mid L_{i j}^{*}>0=X_{i j} \cdot \beta+\delta_{j}+\rho \cdot \sigma_{u} \cdot \lambda_{i j} \\
& \lambda_{i j}=\frac{\phi\left(H_{i j} \cdot \alpha+\omega_{j}\right)}{\Phi\left(H_{i j} \cdot \alpha+\omega_{j}\right)}
\end{aligned}
$$

where $\phi($.$) is the standard normal density distribution function, \Phi($.$) is the standard$ cumulative normal distribution and $\lambda_{i j}$ is the inverse Mills ratio. We can thus test for selection bias $(\rho \neq 0)$ and correct it.

For the model to be identified, we require selection variables: these affect the probability of employment, but not wages directly. We use standard instruments (Aeberhardt et al., 2010a): marital status (single man, single woman, working or non-working spouse) and the presence of at least one child. These significantly affect the probability of employment (Table 2) and can thus be considered as valid.

Table 4 reports wage-equation estimates using two different econometric methods: models (1) and (2) present simple weighted OLS regression results, while models (3) and (4) control for selection bias. In column (1) both experience and seniority have a positive effect on wages. The effect of experience is however non-linear, as shown by the negative coefficient on "Experience2/100". The negative and highly significant coefficients on "NorthAfrican" and "Sub-Saharan African" origin in column (1) indicate an ethnic wage gap. Consistent with previous work, we also see a gender gap in wages.

Unsurprisingly, model (2) indicates that education is an important determinant of wages. Controlling for education, the ethnic wage gap persists but is less significant and smaller in size. Turkish origin attracts a positive coefficient when controlling for education, and Asian and European second-generation immigrants do not significantly differ from French natives in terms of wages. 
Table 4 - Wage equation estimates

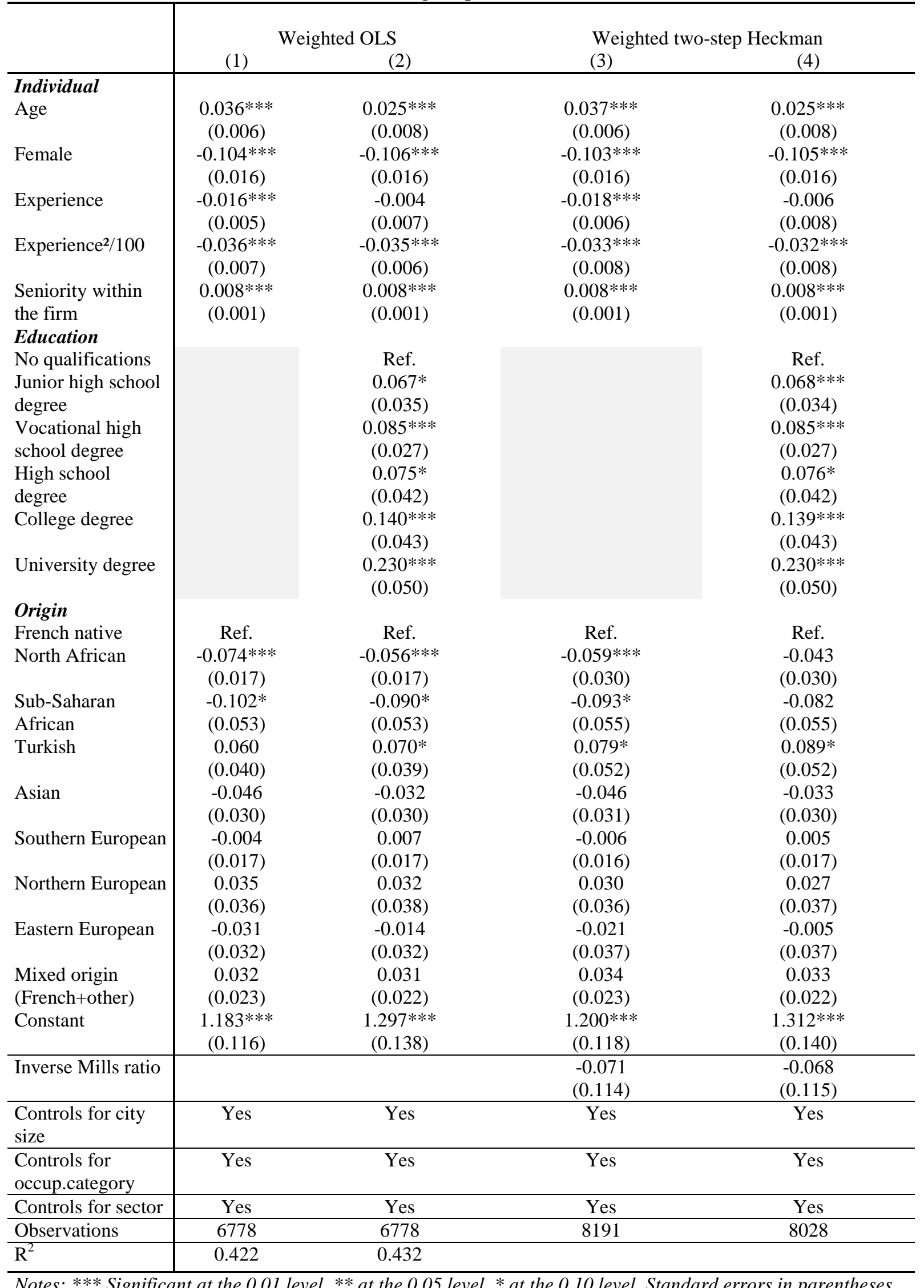


Columns (3) and (4) are analogous to columns (1) and (2), but control for selection bias. That the inverse Mills ratio is insignificant does not necessarily imply that there is no selection bias within each ethnic group. It could also be due to the selection bias being different with respect to both its extent and nature between French natives and secondgeneration immigrants. The "North-African" and "Sub-Saharan African" origin variables are no longer significant in column (4). Finally, the coefficient on the "Turkish" variable shows that Turkish second-generation immigrants benefit from a wage premium relative to natives.

Overall, these results show that, with the exception of those of Turkish origin, ethnic wage gaps completely disappear after controlling for both selection bias and education. This is a generalization of the findings in Aeberhardt et al. $(2010 \mathrm{a}, \mathrm{b})$ which shed light on the heterogeneity between different immigrant types.

To investigate in further details the extent of ethnic wage gap, we resort again to the decomposition methodology proposed by Aeberhardt et al. (2010a). This counterfactual approach, inspired by standard decomposition techniques (Oaxaca, 1973; Blinder, 1973), only requires the estimation of wages for French natives. This avoids the potential problem of small cell sizes by second-generation immigrant groups. We use two simple counterfactuals to decompose the wage gap between French natives $f$ and the second-generation group $j$ :

$$
\begin{aligned}
& w_{j}^{*}=\sum_{i \in j}\left(\frac{\Phi\left(H_{i} \cdot \widehat{\alpha}_{f}\right)}{\sum_{i} \Phi\left(H_{i} \cdot \widehat{\alpha}_{f}\right)}\right)\left(X_{i} \cdot \hat{\beta}_{f}+\hat{\rho}_{f} \cdot \hat{\sigma}_{f} \cdot \frac{\phi\left(H_{i} \cdot \widehat{\alpha}_{f}\right)}{\Phi\left(H_{i} \cdot \widehat{\alpha}_{f}\right)}\right) \\
& w_{j}^{* *}=\sum_{i \in j}\left(\frac{L_{i}}{\sum_{i} L_{i}}\right)\left(X_{i} \cdot \hat{\beta}_{f}+\hat{\rho}_{f} \cdot \hat{\sigma}_{f} \cdot \frac{\phi\left(H_{i} \cdot \widehat{\alpha}_{f}\right)}{\Phi\left(H_{i} \cdot \widehat{\alpha}_{f}\right)}\right)
\end{aligned}
$$

The first counterfactual $w_{j}^{*}$ corresponds to the average wage that an individual from group $j$ could expect if he was selected and paid in the same way as those in the French native group. The second counterfactual $w_{j}^{* *}$ represents the average wage that an employed individual from group $j$ could expect if he was paid in the same way as French natives.

The decomposition of the wage gap between French natives $f$ and second-generation group $j$ is then written as follows :

$$
\bar{w}_{f}-\bar{w}_{j}=\underbrace{\bar{w}_{f}-w_{j}^{*}}_{\text {Explained part }}+\underbrace{w_{j}^{*}-w_{j}^{* *}}_{\text {Selectivity }}+\underbrace{w_{j}^{* *}-\bar{w}_{j}}_{\text {Residual gap }}
$$


Table 5 - Wage gap decomposition between French natives and second-generation immigrants

\begin{tabular}{|c|c|c|c|c|c|c|c|}
\hline & \multirow[b]{2}{*}{ Raw } & \multicolumn{3}{|c|}{ No control for education } & \multicolumn{3}{|c|}{ Controlling for education } \\
\hline & & Explained & Residual & Selection & Explained & Residual & Selection \\
\hline North African & 0.140 & $\begin{array}{c}0.095 \\
67.86 \%\end{array}$ & $\begin{array}{c}-0.024 \\
-17.14 \%\end{array}$ & $\begin{array}{c}0.069 \\
49.28 \%\end{array}$ & $\begin{array}{c}0.100 \\
71.43 \%\end{array}$ & $\begin{array}{c}-0.039 \\
-27.86 \%\end{array}$ & $\begin{array}{c}0.079 \\
56.43 \%\end{array}$ \\
\hline Sub-Saharan & 0.135 & 0.094 & -0.070 & 0.111 & 0.094 & -0.083 & 0.124 \\
\hline African & & $69.63 \%$ & $-51.85 \%$ & $82.22 \%$ & $69.63 \%$ & $-61.48 \%$ & $91.85 \%$ \\
\hline Turkish & 0.131 & $\begin{array}{c}0.219 \\
167.18 \%\end{array}$ & $\begin{array}{c}-0.211 \\
-161.07 \%\end{array}$ & $\begin{array}{c}0.123 \\
93.89 \%\end{array}$ & $\begin{array}{c}0.211 \\
161.07 \%\end{array}$ & $\begin{array}{c}-0.221 \\
-168.70 \%\end{array}$ & $\begin{array}{c}0.141 \\
107.63 \%\end{array}$ \\
\hline Asian & not signif. & & & & & & \\
\hline South European & 0.027 & $\begin{array}{c}0.018 \\
66.67 \%\end{array}$ & $\begin{array}{c}0.053 \\
192.30 \%\end{array}$ & $\begin{array}{c}-0.044 \\
-162.97 \%\end{array}$ & $\begin{array}{c}0.021 \\
77.78 \%\end{array}$ & $\begin{array}{c}-0.053 \\
-196.30 \%\end{array}$ & $\begin{array}{c}0.059 \\
218.52 \%\end{array}$ \\
\hline North European & -0.161 & $\begin{array}{c}-0.072 \\
44.72 \%\end{array}$ & $\begin{array}{l}-0.123 \\
76.40 \%\end{array}$ & $\begin{array}{c}0.034 \\
-21.12 \%\end{array}$ & $\begin{array}{c}-0.078 \\
48.45 \%\end{array}$ & $\begin{array}{c}-0.124 \\
77.02 \%\end{array}$ & $\begin{array}{c}0.041 \\
-25.47 \%\end{array}$ \\
\hline East European & not signif. & & & & & & \\
\hline
\end{tabular}

Note: We can interpret the figures for North African origin (when controlling for education) as follows. 0.140 is the initial raw wage gap figure between North African-origin and French natives. Differences in characteristics explain $71.43 \%$ of this gap. Differences in selection explain $56.43 \%$ of the gap. Overall, the residual gap represents $-27.86 \%$ of the raw gap. That is to say, if French natives and North African-origin immigrants shared the same characteristics and faced the same selection, the wage gap would be inverted, and end up in favor of the latter.

The wage gap between French native and second-generation immigrants with Southern European origin is significant but too small to provide accurate interpretation of its decomposition.

Table 5 presents the ethnic wage gap decomposition results. The wage gap is expressed here as the difference in the log hourly wage between French natives and second-generation immigrants. As noted above, we decompose these gaps into three components. The first corresponds to the proportion explained by differences in observed characteristics between the two groups. The second shows the residual gap, i.e. the proportion of the gap which is neither explained by observed characteristics nor by selection. The third represents the differences between the two groups in terms of selection. The table shows each component as a percentage of the initial raw gap. Again, controlling for education reduces the residual part and increases the explained part of the wage gap. Overall, these and previous findings suggest that education differences between ethnic groups are particularly important in explaining employment and wage gaps. We now turn to the determinants of the education gaps between ethnic groups.

\subsection{Educational achievement gaps between ethnic groups.}

Our previous analyses underlined the central role played by education in explaining labormarket outcomes. We now go one step further and consider the determinants of education. 
We first present some summary statistics; we then show the results of ordered logit estimation of the determinants of education.

\subsubsection{Estimating education}

Table 6 describes the distribution of the highest diploma obtained by the respondent. These figures should be interpreted with caution as the age structure varies widely between groups. Second-generation immigrants are on average six years younger than French natives, and have therefore profited from the structural increase in general education. Even so, secondgeneration immigrants are more likely to have left school without any qualifications and conversely are less likely to have a university degree. This observation does not hold, however, for those of Sub-Saharan African and Asian origin.

Table 6 - Summary education statistics (highest qualification)

\begin{tabular}{l|cccccccc}
\hline & French & North & Sub- & & & Northern & Southern & $\begin{array}{c}\text { Eastern } \\
\text { European } \\
\text { European } \\
\text { European }\end{array}$ \\
\hline (1) No qualifications & $11.57 \%$ & $18.12 \%$ & $11.78 \%$ & $21.88 \%$ & $10.40 \%$ & $10,61 \%$ & $17.22 \%$ & $19.22 \%$ \\
(2) Junior high school & $8.19 \%$ & $8.92 \%$ & $8.45 \%$ & $7.89 \%$ & $8.75 \%$ & $3,60 \%$ & $9.12 \%$ & $9.53 \%$ \\
(3) Vocational high & & & & & & & & \\
school & $40.95 \%$ & $41.94 \%$ & $37.94 \%$ & $50.98 \%$ & $26.79 \%$ & $35,16 \%$ & $42.01 \%$ & $37.99 \%$ \\
(4) High school & $6.07 \%$ & $5.58 \%$ & $4.80 \%$ & $0.90 \%$ & $8.00 \%$ & $18,12 \%$ & $4.61 \%$ & $4.91 \%$ \\
(5) College & $14.06 \%$ & $12.14 \%$ & $16.91 \%$ & $7.04 \%$ & $15.53 \%$ & $8,15 \%$ & $13.99 \%$ & $16.07 \%$ \\
(6) University & $19.16 \%$ & $13.31 \%$ & $20.12 \%$ & $11.31 \%$ & $30.53 \%$ & $24,36 \%$ & $13.05 \%$ & $12.27 \%$ \\
\hline
\end{tabular}

A more formal analysis comes from estimating the determinants of education. The results appear in Table 7: these refer to two ordered logit models of highest qualification and two probit models of schooling failure (defined as no diploma). Following Belzil and Poinas (2010), we use the highest qualification as the attainment variable. Column (1) only controls for demographic variables such as ethnic origin, gender and age. Column (2) then adds family background ${ }^{9}$ and childhood family background: existing research has emphasized family background (e.g. parental education, family income and family structure) as key determinants of education. Parental background may affect child education via various channels. The first is family income. Much work has shown that family income is an important determinant of

\footnotetext{
${ }^{9}$ We also control for school characteristics (only private, only public or both types of schools during schooling), average unemployment and the growth rate when the respondent was aged 15, parental occupation as well as serious events during schooling (parental death, problems with violence, alcohol, and money). These variables are not displayed in Table 7, but are available upon request from the authors.
} 
child school success (Haveman and Wolfe, 1995; Plug and Vijverberg, 2005). ${ }^{10}$ Children from poor families have greater difficulty in pursuing their education as their parents face credit constraints in financing their children's education. As our data do not contain information on parental income, we use the occupation of both the father and the mother during the individual's childhood to proxy for the household financial situation.

Beyond these financial aspects, we also consider parental education as an important determinant of educational attainment: this picks up any intergenerational correlation in education. This correlation may reflect some ability being transferred genetically to children. It may also reflect the transmission of preferences. It can reasonably be argued that highlyeducated parents will place greater value on education, and may therefore be more likely to encourage their children to pursue further education. Furthermore, educated parents may also help their offspring in their schoolwork (e.g. by having books around the house) which may reduce the cost of acquiring education (see for instance Ermisch and Francesconi, 2001).

Finally we also control for family structure (e.g. the number of siblings, being in a singleparent family). Some research has shown that being in a single-parent family during childhood has a negative impact on education (e.g. Haveman and Wolfe, 1995). Having more brothers or sisters might also hamper education via the scarcity of resources (both money and time) in larger families (e.g. Blundell et al. 1997).

Table 7 - Estimating education

\begin{tabular}{l|cc|cc|}
\hline Models & \multicolumn{2}{|c|}{$\begin{array}{c}\text { Diploma ordered logit } \\
(1)\end{array}$} & $(2)$ & \multicolumn{2}{c|}{$\begin{array}{c}\text { Schooling failure probit } \\
(3)\end{array}$} \\
\hline Age & $-0.027 * * *$ & $0.030^{* * *}$ & $0.007 * * *$ & -0.002 \\
& $(0.004)$ & $(0.009)$ & $(0.001)$ & $(0.002)$ \\
Female & $0.144 *$ & $0.224 * * *$ & -0.021 & $-0.028^{*}$ \\
& $(0.076)$ & $(0.08)$ & $(0.017)$ & $(0.016)$ \\
Family background & & & & $-0.046^{* *}$ \\
Separate room & & $0.356^{* * *}$ & & $(0.02)$ \\
& & $(0.103)$ & & $0.018^{* * *}$ \\
Number of siblings & & $-0.123^{* * *}$ & & $(0.004)$ \\
& & $(0.024)$ & & $-0.029 * * *$ \\
Mother's education & & $0.168^{* * *}$ & & $(0.006)$ \\
& & $(0.027)$ & & $-0.019 * * *$ \\
Father's education & & $0.191 * * *$ & & $(0.005)$
\end{tabular}

10 Recently, economists have shown that the existence of a positive relationship between parental income and children's school outcomes may be biased if parental ability is ignored. In recent work, Plug and Vijverberg (2005) show however that this bias may be overestimated. They appeal to a sample of adopted children, which offers genetically-unbiased estimates, and find that family income still has a significant effect. 


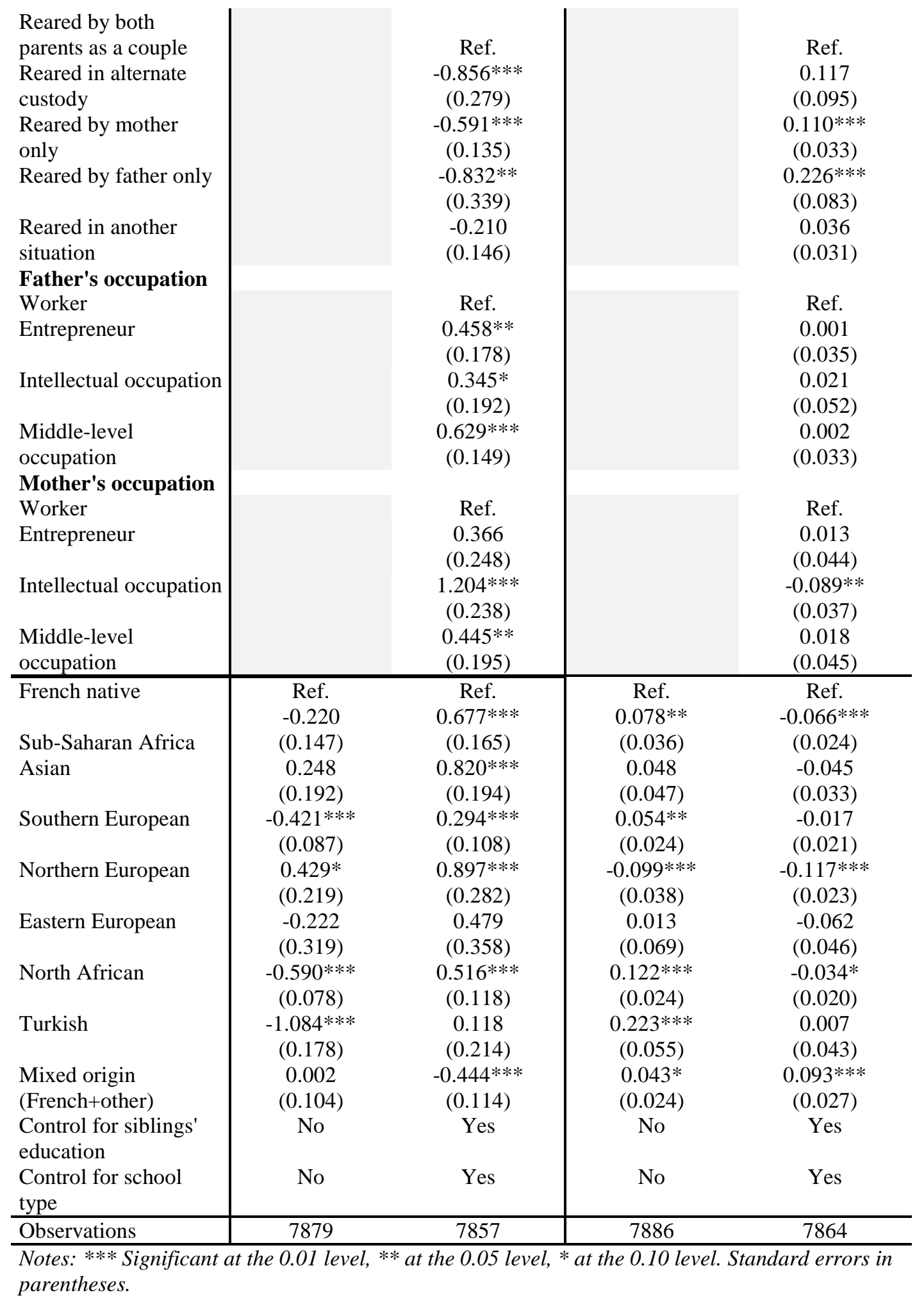

Column (1) shows that women have better education outcomes than do men. The North African, Southern Europe and Turkish origin variables attract negative and significant coefficients, so that these individuals are less likely to experience education success. Those from Sub-Saharan Africa, Asia and Eastern Europe are not significantly different from French 
natives. Finally, second-generation immigrants from Northern Europe perform significantly better than all other groups.

The findings in column (2) are rather different. Here the introduction of family background has a sizeable effect on the ethnic-origin coefficients. These latter are now significantly positive (except for Turkey and Eastern Europe, which are not different from French natives). We no longer find a negative effect of origin on education: instead second-generation immigrants are more likely than French natives to obtain better education outcomes. This result is consistent with the existing literature. Card et al. (2000) use US data (the 1940 and 1970 Censuses and 1994-1996 Current Population Surveys) and find that second-generation immigrants are more educated than the children of comparable U.S.-born parents. Brinbaum et al. (2012) use the same $\mathrm{TeO}$ data as we do, and obtain a similar result showing that ethnic origin is no longer significant as a predictor of schooling failure when family background is controlled for. This result is also consistent with Dustmann et al. (2012), who carry out a comparative analysis across a number of European countries of second-generation immigrants using PISA, European Union Labor Force Survey and European Social Survey data. For example, they find that the test-score gaps between children born to immigrants and natives is substantially reduced in most countries when controls for parental characteristics, school and peer quality, and the language spoken in school are introduced.

Childhood environment thus seems to be a key determinant of life-course success, as it affects education which itself generates labor-force outcomes. Parental education and family income are strongly correlated with child education. In addition, having a single parent is associated with worse education outcomes. The negative impact of the number of siblings on education can reflect that more siblings implies fewer available resources per child. Last, in line with the results of Goux and Maurin (2005), the availability of a separate room for homework is positively associated with education outcomes. This can be seen as additional evidence for the importance of educational resources.

Table 8 shows that ethnic-origin groups are significantly different from French natives with respect to their family background, and explains why ethnic-origin groups have worse educational outcomes than do French natives. We first see that North African, Southern European and Turkish parents are less educated than are French parents and have "no qualification" as the mean educational level for both the father and the mother. Second, second-generation immigrants from North African, Sub-Saharan African, Eastern Europe and 
Turkish parents have fewer opportunities to do their homework in a separate room. Notably, the number of Eastern-European descendants who benefited from a separate room is almost 30 percentage points lower than their French counterparts. For the three other ethnic groups, the difference is at least 8 percentage points. Sub-Saharan and North African (respectively Asian and Turkish) second-generation immigrants live in families with on average two siblings (respectively 0.8 siblings) more than French families. Third, Table 8 indicates that Sub-Saharan, Southern and Eastern European origin respondents were brought up less frequently by both parents in a couple. In particular, the percentage of Sub-Saharan individuals reared by both parents in a couple is 14.6 points lower than the figure for French natives. North African, Southern-European and Turkish parents are on average less educated. Finally, Northern-European immigrants are not significantly different from natives, except for the fact that their parents were more often in a couple relationship.

Table 8 - Ethnic-origin Differences in Family Background

\begin{tabular}{|c|c|c|c|c|c|c|c|}
\hline & $\begin{array}{c}\text { Sub } \\
\text {-Saharan } \\
\text { Africa } \\
\end{array}$ & $\begin{array}{l}\text { North } \\
\text { Africa }\end{array}$ & $\begin{array}{l}\text { Northern } \\
\text { Europe }\end{array}$ & $\begin{array}{l}\text { Southern } \\
\text { Europe }\end{array}$ & $\begin{array}{l}\text { Eastern } \\
\text { Europe }\end{array}$ & Asia & Turkey \\
\hline $\begin{array}{l}\text { Separate room for } \\
\text { homework }\end{array}$ & $-0.081 * * *$ & $-0.103 * * *$ & -0.026 & -0.025 & $-0.298 * * *$ & -0.003 & $-0.092 *$ \\
\hline Number of Siblings & $2.446 * * *$ & $2.385 * * *$ & 0.454 & $0.394 * *$ & 0.081 & $0.851 * * *$ & $0.801 * * *$ \\
\hline Mother's Education & -0.001 & $-0.973 * * *$ & 0.407 & $-0.681 * * *$ & -0.437 & -0.022 & $-1.168 * * *$ \\
\hline Father's Education & -0.112 & $-1.214 * * *$ & 0.176 & $-0.993 * * *$ & $-0.641 *$ & 0.331 & $-1.22 * * *$ \\
\hline $\begin{array}{l}\text { Reared by: } \\
\text { Both parents as a } \\
\text { couple }\end{array}$ & $-0.146 * * *$ & 0.004 & $0.062 * * *$ & $0.04 * * *$ & $0.072 * * *$ & 0.005 & 0.033 \\
\hline Alternate custody & 0.015 & -0.001 & 0.000 & 0.003 & $-0.008 * * *$ & 0.015 & 0.005 \\
\hline Mother only & $0.145^{* * *}$ & $0.025^{*}$ & -0.025 & 0.006 & $-0.037 *$ & $0.073 * *$ & -0.006 \\
\hline Father only & 0.003 & -0.001 & -0.007 & -0.008 & 0.002 & 0.008 & $-0.017 * *$ \\
\hline Other & $0.051 *$ & $-0.031 * * *$ & $-0.034 * *$ & -0.017 & - & -0.024 & -0.017 \\
\hline
\end{tabular}

Notes: *** Significant at the 0.01 level, ** at the 0.05 level, * at the 0.10 level. Parental education is a discrete number between 1 and 6 according to the six education levels in the data (see Table 6). The figures should be read as the difference between the average highest educational qualification between natives and that in the ethnic group under consideration. Given that the average highest educational qualification for the father (mother) of French natives is junior high school (no qualifications), the data show for example that the average qualification for father (mother), of North African secondgeneration immigrants is no qualifications (no qualifications).

Family context may affect schooling success in two different ways. First, migrant descendants are more likely to have unfavorable family backgrounds (as in Table 8). It might also be conjectured that these backgrounds have a more negative impact on them than they would on natives. To investigate this second channel, we run complementary regressions with 
interactions between respondents' ethnic origin and family background (number of siblings, separate room, family structure and parental education). In these regressions (which are available upon request) none of these interaction variables are significant or robust to specification changes, suggesting that family background has a similar effect across ethnic groups. The size, structure and wealth of the family are of the same central importance in predicting education outcomes (see Table 7) for all ethnic groups.

\section{Discussion}

We find that the employment gap between French natives and second-generation immigrants is mainly driven by education. We also show that the ethnic wage gap is substantially reduced by controlling for both selection bias and education. These findings potentially challenge the role of discrimination in explaining ethnic labor-market outcomes. Nevertheless, even after controlling for education, some ethnic variables remain significant, consistent with some residual discrimination. We may be tempted to conclude that while discrimination is not obvious in wages, it is more likely to occur at the hiring stage. We should however be cautious in our interpretation of the residual employment gap. This latter does not necessarily reflect discrimination, but may also come from unobserved differences in ability, attitudes, or preferences. Our inability to accurately identify discrimination is certainly one of the main limitations of our analysis. This is however a general difficulty in most survey data without accurate information on discrimination at the hiring stage. Recent developments in field and laboratory experiments have shown that the experimental method is a valuable tool for the circumvention of this difficulty (See Riach and Rich, 2002, for an exhaustive survey of field experiments; see Larribeau et al., 2013, for the study of discrimination in laboratory settings).

Another important finding here is that childhood environment is a key determinant of education. Controlling for family background knocks out the negative effect of ethnic origin on education. This echoes the explanations found in the sociology of education literature that immigrants believe more than natives that education is a vehicle for social mobility (see for instance Caille and Lemaire, 2009). For that reason, they would invest more into education. 
These insignificant education coefficients may also indicate that second-generation immigrants do not suffer from discrimination at school. ${ }^{11}$ They also do not seem to underinvest in education by anticipating lower returns on the labor market (see for instance the theoretical setups in Lundberg and Startz, 1983; Keane and Wolpin, 2000). ${ }^{12}$ In sharp contrast, the fact that the variables associated with second-generation immigrants become positive and significant after controlling for other variables suggests that they exert more effort, perhaps in order to counteract the potential future effects of discrimination. Finally, our result on the impact of family background on educational attainment, which in turn is key for labor market integration, is also in line with the findings of existing work emphasizing the role of "premarket" factors in adult earnings inequality (see Todd and Wolpin, 2007).

\section{Conclusion}

This paper has considered the wage and employment gaps between French natives and second-generation immigrants, using data from the French Trajectoires et Origines survey. To our knowledge, this dataset is the only one providing accurate information on the life-course of (second-generation) French immigrants. We also evaluate the role of educational differences between ethnic groups in explaining ethnic labor-market gaps. Last, we investigate the determinants of these ethnic gaps in education. We have three main findings.

First, second-generation immigrants are less likely to be employed and receive lower wages than do French natives. However, second-generation immigrants are not homogeneous. We uncover considerable differences by ethnic origin: those with North-African, Sub-Saharan African and Turkish origins have both a lower probability of employment and lower wages than French natives. By way of contrast, second-generation immigrants from Asia or European countries are similar to French natives in terms of both wages and employment.

Second, a large part of the observed outcome differences between French natives and second-generation immigrants is explained by education. This is particularly the case for

\footnotetext{
${ }^{11}$ There is now a growing literature on discriminatory behavior in education evaluating the impact of teachers' behavior on the gap between natives and ethnic groups. For instance, Dee (2005) finds that the student's odds of being seen as inattentive increases significantly by at least 33 percent when the teacher is not of the same race, and Ouazad (forthcoming) underlines that teachers give better assessments to pupils of their own race. These results suggest that the ethnicity of both the teacher and the pupil matters to know whether ethnic minorities suffer from discrimination. Most of this empirical literature has used US data. The TeO survey does not include data that would enable us to address this issue.

${ }^{12}$ In these models, negative prior beliefs about members of a particular group may become self-fulfilling in equilibrium (Lundberg and Startz, 1983). This may occur for example if individuals of a particular group underinvest in human capital due to anticipated discriminatory treatment and therefore a lower return to education.
} 
individuals with North-African or Turkish parents. This key role of education in explaining ethnic labor-market gaps provides an alternative reading to that of ethnic discrimination.

Third, we show that this schooling gap is mainly explained by ethnic differences in family background. The root of labor-market outcomes may then be found in family background, rather than ability, discrimination at school or anticipated discrimination.

It cannot be denied that employer discrimination exists in the French labor market. However, our results suggest that targeting the education gap via family-oriented policies may be at least as efficient as discrimination-oriented policies in reducing ethnic gaps in the labor market. Education policies such as early-childhood education, kindergarten, homework assistance, and so on, which act as a counterweight to aspects of family background, may help to attenuate these education gaps. Future research will help to further determine the precise impact of discrimination in determining outcomes on the French labor market. 


\section{References}

Aeberhardt, R., Fougère, D., Pouget, J., Rathelot, R., 2010a. Wages and employment of French workers with African origin. Journal of Population Economics, 23(3), 881-905.

Aeberhardt, R., Fougère, D., Pouget, J., Rathelot, R., 2010b. L'emploi et les salaires des enfants d'immigrés. Economie et Statistique, 433(1), 31-46.

Aeberhardt, R., Pouget, J., 2010. National origin differences in wages and hierarchical positions. Annals of Economics and Statistics, 99-100, 117-139.

Algan, Y., Dustmann, C., Glitz, A., Manning, A., 2010. The economic situation of first and second generation immigrants in France, Germany, and the United Kingdom. Economic Journal, 120, 4-30.

Altonji, J., Blank, R., 1999. Gender and race in the labor market. Handbook of Labor Economics, 3, 3143-4259.

Bauer, T., Sinning, M., 2008. An extension of the Blinder-Oaxaca decomposition to nonlinear models. Advances in Statistical Analysis, 92(2), 192-206.

Becker, G. S. The Economics of Discrimination. 2d ed. Chicago: University of Chicago, 1971.

Belzil, B., Poinas, F., 2010. Education and early career outcomes of second-generation immigrants in France. Labour Economics, 17(1), 101-110.

Blinder, A., 1973. Wage discrimination: reduced form and structural estimates. Journal of Human Resources, 8(4), 436-455.

Blundell, R., Dearden L. Goodman, A., Reed, H., 1997. Higher Education, Employment and Earnings in Britain, London: Institute for Fiscal Studies.

Borjas, G., 1999. The economic analysis of immigration. Handbook of Labor Economics, 3, 1697-1760.

Borjas, G. J., Stephen G. Bronars. 1989. Consumer discrimination and self- employment. Journal of Political Economy, 97(3), 581-605.

Brinbaum, Y., Mouguérou, L., Primon, J.-L., 2012. Les enfants d'immigrés ont des parcours scolaires différenciés selon leur origine migratoire. Immigrés et descendants d'immigrés en France, Insee Références Editions.

Caille, J.-P., Lemaire, S., 2009. Les bacheliers de "première génération": des trajectoires scolaires et des parcours dans l'enseignement supérieur "bridés" par de moindres ambitions. France, Portrait social, Insee.

Card, D., Di Nardo, J., Eugena, E., 2000. The more things change: immigrants and the children of immigrants in the 1940s, the 1970s, and the 1990s. Issues in the economics of immigration, Georges J. Borjas editor, Chicago: University of Chicago Press.

Dee, T.S., 2005. A teacher like me: Does race, ethnicity, or gender matter? American Economic Review, 95(2), 158-165.

Domingues Dos Santos, M., Wolff, F.-C., 2011. Human capital background and the educational attainment of second-generation immigrants in France. Economics of Education Review, 30(5), 1085-1096.

Dustmann, C., Glitz, A., T., Frattini, 2008. The labour market impact of immigration. The Oxford Review of Economic Policy, 24(3), 477-494. 
Dustmann, C., Frattini, T., Lanzara, G., 2012. Educational achievement of second generation immigrants: an international comparison. Economic Policy, 27(69), 143-185.

Ermisch, J., Francesconi, M., 2001. Family matters: impacts of family background on educational attainment, Economica, 68, 137-156.

Gang, I.N., Zimmerman, K.F., 2000. Is child like parent? Educational attainment and ethnic origin. Journal of Human Resources, 35(3), 550-569.

Goux, E., Maurin, E., 2005. The effect of overcrowded housing on children's performance at school. Journal of Public Economics, 89(5-6), 797-819.

Haveman R., Wolfe, B., 1995. The Determinants of children's attainments: a review of methods and findings. Journal of Economic Literature, 33(4), 1829-1878.

Keane, M., Wolpin, K., 2000. Eliminating race differences in school attainment and labor market success. Journal of Labor Economics, 18(4), 614-652.

Larribeau, S., Masclet, D., Peterle, E., 2013. Que nous apprend l'économie expérimentale sur les différences homme-femme sur le marché du travail ? Revue Française d'Economie, forthcoming.

Lombardo, P., Pujol, J., 2011. Le niveau de vie des descendants d'immigrés. Dossier Niveau de vie et pauvreté des immigrés en 2007, Insee, 37-44.

Lundberg, S., Startz, R., 1983. Private discrimination and social intervention in competitive labor market. American Economic Review, 73(3), 340-347.

Neuman, S., Oaxaca, R., 2004. Wage decompositions with selectivity-corrected wage equations: a methodological note. Journal of Economic Inequality, 2(1), 3-10.

Oaxaca, R., 1973. Male-female wage differentials in urban labor markets. International Economic Review, 14(3), 693-709.

Ouazad, A. Assessed by a teacher like me: Race, gender and subjective evaluations. Education Finance and Policy, forthcoming.

Plug E., W., Vijverberg, 2005. Does family income matter for schooling outcomes? Using Adoptees as a Natural Experiment. Economic Journal, 115, 879-906.

Puhani, P., 2000. The Heckman correction for sample selection and its critique. Journal of Economic Surveys, 14(1), 53-68.

Rao, J., Scott, A., 1984. On Chi-squared tests for multiway contingency tables with cell proportions estimated from survey data. The Annals of Statistics, 12(1), 46-60.

Riach, P., Rich, J., 2002. Field experiments of discrimination in the market place. Economic Journal, 112, 480-518.

Trajectoires et origines $(\mathrm{TeO})$ - version complète - 2008 - (2008) [Fichier électronique], INED et INSEE [producteur], Centre Maurice Halbwachs (CMH) [diffuseur].

Todd, P., Wolpin, K., 2007. The production of cognitive achievement in children: home, school and racial test score gaps. Journal of Human Capital, 1(1), 91-136.

Van ours, J.C., J., Veenman, 2001. The educational attainment of second-generation immigrants in the Netherlands. Journal of Population Economics, 16(4), 739-753. 